\title{
ZAKAT DALAM MENDORONG PERTUMBUHAN EKONOMI DAN PENGENTASAN KEMISKINAN
}

\author{
Sundari, Muhammad Mujtaba Mitra Zuana \\ Institut Pesantren KH. Abdul Chalim Mojokerto \\ Email: Sundarifreste89@gmail.com, mujtaba.mitrazuana@ikhac.ac.id
}

\begin{abstract}
This study aims to analyze empirically whether zakat has an impact on efforts to reduce the level of poverty. As the main problem faced by the Indonesian people is the problem of poverty. From several analysis results show that zakat can reduce the number and percentage of poor families, and reduce the depth and severity of poverty. The results revealed that the provision of productive zakat capital in the form of business capital has a positive impact and can reduce the poverty rate. Therefore, the provision of productive zakat in the form of venture capital can be continued and upgraded.In addition to the need to develop the distribution of zakat to micro small medium enterprises (SMEs) or group of joint ventures (KUBE) so that there is collaboration and synergy between individuals. Based on the results of the study there is a positive influence between the utilization of productive zakat programs LAZ An-Naafi 'Boyolali to income mustahiq. That income mustahiq influenced by the utilization of productive zakat with a large contribution of influence is $30.5 \%$. This can be seen from the development of income and fulfillment needs mustahiq after following the program of productive zakat empowerment LAZ An-Naafi 'Boyolali which can also be used for venture capital.
\end{abstract}

Keywords: Zakah, giver of zakat, recipient of zakat, welfare

\begin{abstract}
ABSTRAK
Penelitian ini bertujuan untuk menganalisis secara empiris apakah zakat berdampak pada upaya mengurangi tingkat kemiskinan. Sebagai masalah utama yang dihadapi oleh masyarakat Indonesia adalah masalah kemiskinan. Dari beberapa hasil analisis menunjukkan bahwa zakat dapat mengurangi jumlah dan persentase keluarga miskin, dan mengurangi kedalaman dan tingkat keparahan kemiskinan. Hasil penelitian mengungkapkan bahwa penyediaan modal zakat produktif dalam bentuk modal bisnis memiliki dampak positif dan dapat mengurangi tingkat kemiskinan. Oleh karena itu, penyediaan zakat produktif dalam bentuk modal ventura dapat dilanjutkan dan ditingkatkan. Selain itu perlu dikembangkan distribusi zakat untuk usaha mikro kecil menengah (UKM) atau kelompok usaha patungan (KUBE) sehingga ada kolaborasi dan sinergi antar individu. Berdasarkan hasil penelitian terdapat pengaruh positif antara pemanfaatan program zakat produktif LAZ An-Naafi 'Boyolali terhadap pendapatan mustahiq. Pendapatan itu mustahiq dipengaruhi oleh pemanfaatan zakat produktif dengan kontribusi pengaruh besar adalah 30,5\%. Ini bisa dilihat dari perkembangan pendapatan dan pemenuhan kebutuhan mustahiq setelah mengikuti program pemberdayaan zakat produktif LAZ An-Naafi 'Boyolali yang juga bisa digunakan untuk modal.
\end{abstract}

Kata kunci: Zakat, pemberi zakat, penerima zakat, kesejahteraan

\section{PENDAHULUAN}

Dewasa ini ada perkembangan menarik dalam kesadaran beragama di lapisan umat Islam di Indonesia terutama dalam kesadaran berzakat, bershadaqah dan berinfak. 
Hal itu dapat ditunjukkan dengan banyak lembaga-lembaga pengelola zakat baik yang dikelola masyarakat maupun pemerintah. Dengan didirikannya lembaga tersebut tentunya bukan tanpa maksud dan tujuan akan tetapi untuk melayani para wajib zakat supaya dapat menyalurkan zakatnya dengan mudah. Zakat sebagai salah satu rukun Islam mempunyai peran penting dalam dunia nyata. Peranan zakat baik zakat harta maupun zakat fithrah sebagai sarana komunikasi utama dari masyarakat yang mampu dengan masyarakat yang tidak mampu. Dengan adanya sarana zakat ini akan terjadi pemerataan pendapatan yang lebih kentara kalau dihubungkan dan dilaksanakan bersama secara baik dan benar (Ali). Hal yang penting lagi adalah dengan zakat tersebut tidak menghilangkan sirkulasi kekayaaan dan menghilangkan keseimbangan dalam distrisbusi harta kekayaan di antara kegiatan manusia (Maududi, 2005). Sejauh mana peran zakat tersebut dalam menyelesaikan persoalan sosial-ekonomi umat, sehingga Islam sebagai rahmatal lil'alamiin benar-benar dapat dirasakan. Namun tampaknya antara idealitas tersebut masih jauh dari realitas yang ada. Hal itu dapat dilihat ketika musim pembagian zakat (fitrah pada hari raya Idul Fitri), masyarakat (muslim) di Indonesia masih berjubel berdesakan dan berantrian untuk mendapatkan zakat. Padahal jika zakat benar-benar dikelola dengan manajemen yang Zakat Dalam Mendorong Pertumbuhan Ekonomi Dan Pengentasan Kemiskinan

\section{LANDASAN TEORI}

Zakat adalah salah satu pilar penting dalam ajaran Islam.Secara etimologis, zakat memiliki arti kata berkembang (an-namaa), mensucikan (at-thaharatu) dan berkah (albarakatu).Sedangkan secara terminologis, zakat mempunyai arti mengeluarkan sebagian harta dengan persyaratan tertentu untuk diberikan kepada kelompok tertentu (Mustahik) dengan persyaratan tertentu pula (Hafidhuddin, 2002).

Menurut Darajat (1991:212) zakat berasal dari “zakka”yang berarti suci, berkah, tumbuh berkembang dan terpuji. Sedangkan dari segi istilah zakat adalah sejumlah harta tertentu yang diwajibkan Allah SWT yang diserahkan kepada orang yang berhak menerimanya, di samping berarti mengeluarkan dalam jumlah tertentu itu sendiri. Razak (1996:186) menambahkan zakat berasal dari kata tazkiyah yang artinya mensucikan.Oleh karenanya zakat berarti mensucikan harta benda dan diri 
pribadi.Berdasar dari pengertian tersebut bahwa zakat maal berfungsi membersihkan harta benda dari orang-orang mampu (kaya). Menurut Tho in (2017: 163) Zakat merupakan konsep ibadah yang diajarkan oleh agama Islam dengan memberikan berbagai kemaslahatan baik untuk mustahik (penerima zakat) maupun muzakki (pemberi zakat). Dengan demikian kedua-duanya mendapatkan manfaat yang sangat besar.

Sedangkan Kementerian Agama RI melalui www.kemenag.go.id menjelaskan zakat adalah harta yang wajib disisihkan oleh seorang muslim atau badan yang dimiliki oleh seorang muslim sesuai dengan ketentuan agaman untuk diberikan kepada yang berhak menerimannya. Berdasar dari pengertian Kementerian Agama RI diatas, bahwa zakat ternyata tidak hanya berlaku pada individu namun juga melekat kewajibannya terhadap badan/lembaga/institusi.Di samping itu para Ulama sekarang harus mulai mengkonsep dan mengembangkan pada zakat lembaga atau institusi.

\section{PENGERTIAN ZAKAT PRODUKTIF}

Zakat produktif adalah zakat yang dikelola dengan cara produktif, yang dilakukandengan cara pemberian modal usaha kepadapara fakir dan miskin sebagai penerima zakatdan kemudian dikembangkan, untuk memenuhikebutuhan hidup mereka untuk masa yang akan datang (Asnainu, 2008). Zakat produktif jelas berbeda dengan zakat konsumtif, karena penyaluran zakat konsumtif berbentuk pemberian dana langsung berupa santunan sebagai bentuk pemenuhan kebutuhan pokok penerima (mustahik) seperti untuk makan,pakaian, biaya sekolah dan lain-lain yang berkaitan dengan kebutuhan sehari-hari. Dengan kata lain, zakat konsumtif adalah untuk kebutuhan yang habis pakai, sementara zakat produktif akan memberikan efek berganda (multiplier effect) karena adanya perputaran yang dapat menghasilkan dan terus berputar.

Qadir (2001) mengemukakan bahwa zakat produktif yaitu zakat yang diberikan Zakat Dalam Mendorong Pertumbuhan Ekonomi Dan Pengentasan Kemiskinan. Keberadaan zakat produktif diperkuati oleh El-Din (dalam Beik, 2009) yang mencoba untuk menganalisa fungsi alokatif dan stabilisatorzakat dalam perekonomian. Dinyatakan bahwa fungsi alokatif zakat diekspresikan sebagaialat atau instrumen untuk memerangi kemiskinan.Namun demikian, hendaknya dalam polapendistribusiannya, 
zakat tidak hanya diberikan dalam bentuk barang konsumsi saja melainkanjuga dalam bentuk barang produksi.Ini dilakukan ketika mustahik memiliki kapasitas dankemampuan untuk mengolah dan melakukan aktivitas produksi. Selain itu perlu didorong distribusizakat dalam bentuk ekuitas, yang diharapkan akan memberikan dampak yang lebih luas terhadapkondisi perekonomian.

Yusuf Al-Qardhawi (dalam Nawawi, 2010:76) menyatakan bahwa pemerintah Islam diperbolehkan membangun pabrik-pabrikatau perusahaan-perusahaan dari uang zakat untuk kemudiankepemilikan dan keuntungannya digunakan bagi kepentingan fakir miskin,sehingga kebutuhan mereka dapat terpenuhi sepanjang masa.

Memperkuat pernyataan di atas Permono (1992:41) menggambarkan mengenaipendayagunaan zakat produktif adalah mengenai syarat bagi harta yang wajib dikenaizakat diantaranya adalah mengandung unsur:

a. al-maliyat atau al-iqtisadiyat (unsur ekonomis)

b. al-nama' atau al-istinma' (unsur produktif atau dapat diproduktifkan)

c. al-milk al-tam(dimiliki secara sempurna)

d. al-kharij'an al hajah al-asliyyah (di luar kebutuhan primer)

e. tamam al nisab (sempurna satu nisab)

f. al-salamah min al-dain (selamat dari hutang)

g. haulan al haul au tamam al hasad (mencapai satu tahun atau panen kering)

\section{ANTARA ZAKAT, INFAK, SHADAQAH, WAKAF DAN HIBAH}

Kelima hal di atas potensi-potensi umat yang dapat diberdayakan untuk kesejahteraan dan kemajuan umat. Secara sekilas kelima hal tersebut sulit diketahui perbedaannya. Berikut diuraikan secara ringkas masing-masing pengertiannya.

\section{Zakat}

Zakat adalah bagian dari harta yang wajib diberikan oleh setiap muslim yang memenuhi syarat kepada orang-orang tertentu dengan syarat-syarat tertentu pula. Dari segi bahasa zakat berasal dari kata "zaka" yang berarti berkah, tumbuh, suci, bersih dan baik (Wasilah, 2005). Maka segala sesuatu yang tumbuh dan berkembang wajib dizakati. Zakat dapat dibedakan menjadi dua yang pertama, zakat mal atau zakat harta adalah bagian dari harta kekayaan seseorang (juga badan hukum) yang wajib dikeluarkan yang 
sudah mencapai nishab (ukuran tertentu) dan sudah mencapai haul, untuk golongan tertentu dalam jumlah minimal tertentu pula. Kedua zakat fithrah yaitu pengeluaran yang wajib dikeluarkan oleh setiap muslim yang mempunyai kelebihan nafkah keluarga yang wajar pada malam dan hari raya Idul Fitri. Zakat fithrah ini adalah berupa kebutuhan atau makanan pokok sebanyak 2,5 $\mathrm{kg}$ atau 3,5 liter.

Mengenai zakat ini Pemerintah telah mengatur dalam UU. No.23 Tahun 2011 Zakat Dalam Mendorong Pertumbuhan Ekonomi Dan Pengentasan Kemiskinan Tentang Pengelolaan Zakat. Dalam UU. No.23 Tahun 2011 tersebut bahwa zakat dapat dikelola oleh Pemerintah maupun masyarakat Muslim. Supaya zakat dapat berfungsi secara optimal maka perlu dipertimbangkan bagaimana cara menghimpun, mendistribusikan serta memberdayakan zakat tersebut supaya seperti yang menjadi tujuannya.

\section{Infak}

Infak adalah pengeluaran sukarela yang dilakukan seseorang setiap kali memperoleh rezeki, sebanyak yang dikehendaki sendiri.

\section{Shadaqah atau sedekah}

Shadaqah atau sedekah yaitu pemberian sukarela yang dilakukan oleh seseorang kepada orang lain, terutama kepada orang-orang miskin, setiap kesempat an terbuka yang tidak ditentukan baik jenis, jumlah maupun waktunya. Sedekah dapat berupa material maupun non material. Secara non material dapat berwujud ilmu ataupun senyum seseorang kepada orang lain, kemudian bertasbih, takbir, tahmid dll, seperti yang terdapat dalam hadis Nabi.

\section{Wakaf}

Wakaf artinya menahan. Maksudnya menahan sesuatu yang benda yang kekal zatnya untuk diambil manfaatnya sesuai dengan ajaran Islam. Orang yang berwakaf tidak lagi berhak atas barang atau benda yang diwakafkannya. Menurut Tho in (2015) bahwa wakaf adalah harta benda seseorang atau person yang diberikan untuk publik agar dapat dimanfaatkan selama barang itu tetap ada.

\section{Hibah}

Hibah adalah pengeluaran harta semasa hidup atas dasar kasih sayang untuk kepentingan seseorang atau untuk kepentingan sesuatu badan sosial, keagamaan, ilmiah, 
juga kepada seseorang yang berhak menjadi ahli warisnya. Pada intinya adalah pemberian suatu benda semasa hidup seseorang tanpa mengharapkan balasan.

Orang yang wajib mengeluarkan zakat yaitu orang muslim yang sudah dewasa yang sehat akalnya, merdeka dan memiliki kekayaan dalam jumlah tertentu dengan syarat-syarat yang ditetapkan syara ${ }^{e e}$ Kewajiban menunaikan zakat adalah berdasarkan Alqurean dan Hadis. Sedangkan orang yang menerima zakat apa yang disebut delapan ashnaf atau golongan yang berhak mendapatkan shadaqah atau zakat (Ad-Dzakiey, 2005) :

\section{a. Orang-Orang Fakir}

Menurut jumhur Ulama, yang disebut fakir adalah orang yang tidak mempunyai harta atau penghasilan banyak dalam memenuhi keperluaannya : sandang, pangan dan papan dan segala keperluan pokok lainnya, baik untuk diri sendiri ataupun bagi mereka yang menjadi tanggungannya. Sedangkan Hamka (1985) menjelaskan dalam Tafsir Al Azhar-nya menyatakan bahwa fakir adalah asal artinya "membungkuk tulang punggung", kemudian diambil maksud dari arti tersebut orang yang membungkuk tulang punggungnya karena memikul beban berat (hidup).

b. Orang-Orang Miskin

Menurut jumhur Ulama, yang disebut miskin adalah mereka yang mempunyai harta atau penghasilan yang layak dalam memenuhi kebutuhannya dan orang yang menjadi tanggungannya, tetapi tidak sepenuhnya tercukupi, seperti misalnya yang diperlukan sepuluh tetapi yang ada hanya tujuh atau delapan. Menurut Hamka miskin dari kata sukuun yang artinya Zakat Dalam Mendorong Pertumbuhan Ekonomi Dan Pengentasan Kemiskinan "berdiam diri" atau menahan penderitaan hidup. Oleh sebab itu tidaklah ada salahnya kalau ada yang berpendapat bahwa fakir dan miskin adalah satu jenis.

c. Pengurus zakat atau Amil Zakat

Yang dimaksud dengan amil zakat adalah mereka yang melaksanakan segala kegiatan urusan zakat, mulai dari para pengumpul sampai kepada bendahara dam para penjaganya. Demikian pula para pencatatnya sampai kepada penghitung yang mencatat keluar masuk zakat dan membagi kepada yang berhak. Allah menyediakan upah bagi mereka dari harta zakat sebagai imbalan dan diambil dari harta zakat. 
Untuk menjaga profesionalisme dari amil zakat maka diperlukan beberapa syarat yang harus dipenuhi:

1) Muslim

2) Seorang mukallaf yaitu orang dewasa yang sehat akal pikirannya.

3) Jujur

4) Memahami hukum zakat

5) Memiliki kemampuan untuk melaksanakan tugas

6) Diutamakan laki-laki

7) Seorang yang merdeka bukan budak

8) Golongan Muallaf

Yang dimaksud dengan golongan muallaf adalah mereka yang diharapkan kecenderungan hatinya atau keyakinannya dapat bertambah terhadap Islam atau terhalang niat jahat mereka atas kaum Muslimin atau harapan adanya kemanfaatan mereka dalam membela dan menolong kaum muslimin dari musuh.

a) Yusuf Qardawi (dalam Adz-Dzakiey, 2005) membagi kelompok muallaf ke dalam tujuh kelompok yaitu: . Golongan yang diharapkan keislamannya atau keislaman kelompok keluarganya seperti halnya yang terjadi masa Fathu Makkah.

b) Golongan orang yang dikhwatirkan perbuatan jahatnya. Mereka dimasukkan ke dalam kelompok mustahik zakat, dengan harapan dapat mencegah kejahatannya. Dalam hadis riwayat Ibnu Abbas dikatakan bahwa ada suatu kaum datang kepada Nabi SAW yang apabila mereka diberi bagian dari zakat maka mereka mengatakan bahwa Islam adalah agama yang baik, tetapi apabila tidak diberi mereka mencelanya.

c) Golongan orang yang baru masuk Islam. Golongan ini diberi zakat supaya lebih mantap keyakinannya terhadap Islam.

d) Pemimpin atau tokoh masyarakat yang telah memeluk Islam yang mempunyai sahabat-sahabat yang masih kafir. Supaya dengan zakat dapat menarik simpati mereka untuk memeluk Islam. E

e) Pemimpin dan tokoh Muslimin yang berpengaruh di kalangan kaumnya tetapi masih mempunyai iman yang masih lemah dengan harapan imannya tetap dan 
kuat sehingga mau memotivasi dirinya dan orang lain untuk berjihad di jalan Allah.

f) Kaum Muslimin yang bertempat tinggal di perbatasan dan benteng dekat musuh dengan harapan dapat mempertahankan diri dan membela kaum Muslimin lainnya yang tinggal jauh dari perbatasan dan benteng dari serbuan musuh. Golongan yang membutuhkan untuk mengurus zakat orang yang tidak mau mengeluarkan kecuali dengan paksaan seperti dengan cara perang. Dalam hal ini zakat untuk memperlunak hati mereka.

g) Orang yang berhutang (gharimiin):Yang dimaksud orang yang berhutang adalah mereka yang memiliki tanggungan hutang atau pinjaman kepada orang lain atau suatu lembaga dalam rangka memenuhi kebutuhan sendirinya atau keluarganya, sedangkan mereka tidak mampu lagi untuk membayar atau melunasi hutang tersebut karena telah jatuh miskin dan menderita. Hamka (1985) menambahkan orang yang terdesak atau terlilit utang dapat mengajukan untuk mendapatkan zakat, sehingga utang tersebut dapat dibayar. Seseorang yang hendak berzakatpun dapat mengatakan terus terang kepada orang yang berhutang kepadanya, bahwa dia bersedia membayar zakatnya, asal saja dengan zakat itu hutangnya dibayarkan.

h) Orang yang berjuang di jalan Allah (fi sabiilillah):Orang yang berjuang di jalan Allah bukan hanya berperang saja melainkan segala sesuatu yang dilakukan untuk menegakkan agama Allah sedangkan mereka tidak mendapatkan bayaran dari siapapun sedangkan untuk mencari nafkah untuk keluarganya sudah tidak ada lagi waktu dan tenaga.

i) Orang yang dalam perjalanan (ibnu sabiil) :Ibnu Sabiil menurut jumhur Ulama adalah kiasan dari musafir (orang yang dalam perjalanan) dan orang yang dalam perjalanan berhak mendapatkan zakat meskipun orang tersebut kaya. Mengapa musafir mendapatkan bagian dari zakat karena Islam sangat menganjurkan untuk bepergian dengan membaca ayat-ayat Tuhan. Yang termasuk dalam perjalanan yang dimaksud adalah bepergian untuk mencari rezeki, untuk menuntut ilmu, untuk berjihad atau berperang di jalan Allah dan perjalanan haji ke tanah suci. 


\section{HIKMAH DIWAJIBKANNYA ZAKAT}

Dengan ditunaikannya zakat maka akan mempunyai hikmah yang besar bagi manusia yaitu:

1. Bagi Yang Bezakat

a. Diri akan menjadi bersih, suci dan sehat dari penyakit kikir, rakus, tamak, sombong dll.

b. Diri akan menerima pencerahan nur ketuhanan sehingga ia dapat merasakan kenikmatan dan kebahagiaan yang hakiki.

c. Hadirnya kekuatan untuk selalu besyukur dan sangat memahami rasa terima kasih terhadap Allah SWT atas apa yang dianugrahkan.

d. Dengan zakat maka yang mempunyai harta akan terbebas dari kikir yang merusak.

2. Pada Harta Benda yang dizakatkan,

a. Harta benda yang dizakatkan akan terlepas dari kezaliman dan kerusakan orang lain.

b. Hadirnya keberkahan dalam harta benda atau kekayaan yang dimiliki. Dengan banyak mengeluarkan zakat maka harta tidak semakin berkurang justru akan semakin bertambah.

c. Dengan harta benda yang dizakati maka akan membersihkan harta benda yang ada.

3. Bagi Yang Menerima Zakat

a. Menghilangkan sifat dengki dan dendam dari orang-orang yang fakir dan miskin yang lemah keimanan dan keislamannya terhadap orang yang kaya.

b. Meringankan kesulitan hidup individu, anggota keluarga dan masyarakat secara finansial-material sehingga terwujud kehidupan yang harmoni.

c. Membimbing dan mengantarkan individu, keluarga dan masyarakat yang menerima zakat kepada pemahaman, pengamalan dan pengalaman yang timbul dari rasa kasih sayang.

\section{PENGARUH ZAKAT TERHADAP PEREKONOMIAN}


Zakat dapat dijadikan sebagai salah satu bentuk modal bagi usaha kecil. Dengan demikian, zakat memiliki pengaruh yang sangat besar dalam berbagai hal kehidupan umat, di antaranya adalah pengaruh dalam bidang ekonomi. Pengaruh zakat yang lainnya adalah terjadinya pembagian pendapatan secara adil kepada masyarakat Islam. Dengan kata lain, pengelolaan zakat secara profesional dan produktif dapat ikut membantu perekonomian masyarakat lemah dan membantu pemerintah dalam meningkatkan perekonomian negara, yaitu terberdayanya ekonomi umat sesuai dengan misi-misi yang diembannya. Diantara misi-misi tersebut adalah Muhammad dan Ridwan Mas ${ }^{e} u d$ (2005):

1. Misi pembangunan ekonomi dan bisnis yang berpedoman pada ukuran ekonomi dan bisnis yang lazim dan bersifat universal.

2. Misi pelaksanaan etika bisnis dan hukum;

3. Misi membangun kekuatan ekonomi untuk Islam, sehingga menjadi sumber dana pendukung dakwah Islam

\section{HASIL DAN PEMBAHASAN}

Berdasarkan hasil analisis regresi sederhana menunjukkan bahwa pendayagunaan zakat produktif pada berpengaruh secara signifikan terhadap peningkatan pendapatan mustahik penerima program. Melalui analisis regresi sederhana didapatkan bahwa pendayagunaan zakat produktif dan penambahan pendapatan mustahik memiliki nilai korelasi yang sedang yaitu dengan nilai pearson correlation sebesar 0,56 . Selain itu, diketahui bahwa pendayagunaan zakat produktif berpengaruh positif terhadap peningkatan pendapatan mustahiq dilihat dari hasil hubungan linier sederhana yang diperoleh yaitu $\mathrm{Y}=8,49+0,50 \mathrm{X}$.

Adapun pengaruh nilai kontribusi pendayagunaan zakat produktif terhadap peningkatan pendapatan mustahik adalah sebesar $31,00 \%$ sedangkan sisanya dipengaruhi oleh variabel lain yang tidak dibahas dalam penelitian ini. Hal tersebut dibuktikan dengan dilakukannya pengujian hipotesis (uji t) atau uji parsial. Berdasarkan uji hipotesis (uji t) didapatkan nilai t hitung untuk variabel $\mathrm{X}$ (pendayagunaan zakat produktif) sebesar 3,75 dengan hasil signifikansinya sebesar 0,001 dan adapun untuk $\mathrm{t}$ 
tabel dengan degree of freedom $=\mathrm{n}-2$, diperoleh nilai sebesar 2,04 sehingga nilai t hitung $(3,746)^{-}$t tabel $(2,042)$.

Dari penjelasan tersebut dapat diartikan bahwa peningkatan pendapatan mustahik akan meningkat jika pendayagunaan zakat produktif juga ditingkatkan, atau pendayagunaan zakat produktif secara signifikan berpengaruh positif terhadap peningkatan pendapatan mustahiq. Hasil uji hipotesis (uji t) tersebut dapat diperkuat dari hasil wawancara kepada bagian pemberdayaan program zakat produktif LAZ AnNaafie $^{\text {ee }}$ Boyolali mengenai optimisme program pemberdayaan melalui pendayagunaan zakat produktif dalam rangka peningkatan pendapatan mustahiq didasarkan oleh hal-hal berikut ini:

1. Dengan adanya program zakat produktif LAZ An-Naafie Boyolali ini mustahik penerima program dapat memperoleh tambahan penghasilan..

2. Dengan adanya program ini mustahik penerima program dapat melakukan usaha secara mandiri dari pendapatan yang diterima. Dimana pendapat atau hasil wawancara tersebut juga dibenarkan oleh salah satu mustahiq penerima program yang mengatakan bahwa mereka dapat memperoleh pendapatan tambahan untuk modal produktif.

\section{KESIMPULAN}

1. Terdapat pengaruh positif antara pendayagunaan program zakat produktif LAZ An-Naafie Boyolali terhadap pendapatan mustahiq. Bahwa pendapatan mustahiq dipengaruhi oleh pendayagunaan zakat produktif dengan besar sumbangan pengaruh adalah 30,5\%. Hal tersebut dapat dilihat dari perkembangan pendapatan dan pemenuhan kebutuhan mustahiq setelah mengikuti program pendayagunaan zakat produktif LAZ An-Naafi ${ }^{\text {ee }}$ Boyolali yang juga dapat digunakan untuk modal usaha.

2. Berdasarkan hasil penelitian adanya keterbatasan penelitian ini adalah kurang lengkapnya dalam pengkajian untuk jumlah sampel dan dari sisi muzaki, supaya dengan adanya tambahan dana zakat dengan sendirinya akan meningkat. Di samping itu penelitian dengan pendekatan kualitatif maupun kuantitatif. 
3. Penelitian tentang faktor-faktor lain dalam pendayagunaan zakat yang dapat mempengaruhi pendapatan mustahiq atau variabel-variabel lain juga layak untuk diteliti lebih lanjut.

4. Untuk LAZ An-Naafie Boyolali sebagai lembaga pengelola zakat hendaknya untuk kedepannya dapat mengoptimalkan pendayagunaan zakat produktif dengan pendampingan atau pelatihan manajemen dan arahan-arahan terkait dengan pendayagunaan zakat produktif.

\section{DAFTAR PUSTAKA}

Adz-Dzakiey. Hamdani Bakran. 2005. Prophetic Inteligence: Kecerdasan Kenabian. Yogyakarta: Islamika.

Al Maududi, Abul A' la. 2005. Asas Ekonomi Islam Al Maududi, Terj.Imam Munawwir. Surabaya: PT BINA ILMU.

Ali, Muhammad Daud. 1988. Sistem Ekonomi Islam: Zakat dan Wakaf. Jakarta: Penerbit Universitas Indonesia,

Asnainu. 2008. Zakat Produktif dalam Perspektif Islam. Bengkulu: Pustaka Pelajar.

Darajat, Zakiah. 1991. Dasar-Dasar Agama Islam, Bulan Bintang, Jakarta.

Hafidhuddin, D. 2002. Zakat dalam Perekonomian Modern.Gema Insani Press, Jakarta.

Hamka. 1985. Tafsir Al Azhar Juzu' X. Jakarta: Pustaka Panjimas. Zakat Dalam Mendorong Pertumbuhan Ekonomi Dan Pengentasan Kemiskinan ISSN: 24776157 JURNAL ILMIAH EKONOMI ISLAM VOL. 03. NO. 01, MARET 2017 51.

Inayah, Gazi. 2003. Teori Komprehensif Tentang Zakat dan Pajak, Terj. Zainuddin Adnan dan Nailul Falah. Yogyakarta: PT. Tiara Wacana.

Irfan Syauqi Beik, Analisis Peran Zakat Dalam Mengurangi Kemiskinan: Studi Kasus Dompet Dhuafa Republika, Jurnal Pemikiran dan Gagasan - Vol II 2009

Lailiyatun Nafiah, Pengaruh Pendayagunaan Zakat Produktif Terhadap Kesejahteraan Mustahiq Pada Program Ternak Bergulir Baznas Kabupaten Gresik, Jurnal eLQist - Vol. 05, No. 01, April 2015. 
Mila Sartika: Pengaruh Pendayagunaan Zakat Produktif terhadap Pemberdayaan Mustahiq pada LAZ Yayasan Solo Peduli Surakarta, Jurnal Ekonomi Islam Vol. II, No. 1, Juli 2008

Muhammad dan Ridwan Maseeud 2005. Zakat dan Kemiskinan Instrumen Pemberdayaan Ekonomi Umat. (Yogyakarta: UII Press).

Multifiah, Pengaruh Zakat, Infak, Shodaqoh terhadap Kesejahteraan Rumah Tangga Miskin, Jurnal Ilmu-Ilmu Sosial, Vol.21 No. 1 Februari 2009.

Nawawi, Ismail. 2010. Zakat Dalam Prespektif Fiqh, Sosial \& Ekonomi, Putra Media Nusantara: Surabaya.

Qadir, A. 1998. Zakat dalam Dimensi Mahdah dan Sosial.Jakarta: Raja Grafindo Persada.

Razak, Nasrudin. 1996. Dienul Islam, Al Maearif Bandung

Rusli, dkk, Analisis Dampak Pemberian Modal Zakat Produktif Terhadap Pengentasan Kemiskinan Di Kab. Aceh Utara, Jurnal Ilmu Ekonomi Pascasarjana Universitas Syiah Kuala Vol. 1, No. 1, Februari 2013.

Tho ${ }^{e e}$ in, Muhammad. 2017. Pembiayaan Pendidikan Melalui Sektor Zakat. Jurnal AlAmwal IAIN Cirebon. Vol. 9 No. 2, hal. 162-175.

Tho ie in, Muhammad dan Iin Emy Prastiwi. 2015. Wakaf Tunai Perspektif Syariah. Jurnal Ilmiah Ekonomi Islam, LPPM STIE AAS Surakarta. Vol. 1 No. 1, Maret 61-74. Undang-Undang Republik Indonesia Nomor 23 Tahun 2011 Tentang Pengelolaan Zakat. Wasilah dan Sri Nurhayati. 2005, Akuntansi Syariah Di Indonesia, Jakarta: Salemba Empat. 